\title{
Pengawasan Dan Keseimbangan Antara DPR Dan Presiden Dalam Sistem Ketatanegaraan RI
}

\author{
Oleh: M. Arsyad Mawardi \\ Hakim Pengadilan Agama Jakarta \\ e-mail:
}

\begin{abstract}
Among the goals of the 1945 constitution amendment is to create the balance among the legislative, executive and judicative powers, and thus the check and balance function may take place. So as the proposal for enhancing the authority of the parliament members, which is according to the second amendment hold the supervisory function as has been provided by section 20 (1).
\end{abstract}

Keywords: Pengawasan, keseimbangan, sistem ketatanegaraan RI

\section{Pendahuluan}

Undang-Undang Dasar 1945 sebelum diadakan perubahan memberikan kekuasaan yang besar atau dominan kepada eksekutif (Presiden). Akibatnya melahirkan pemerintahan otoriter, sehingga UUD 1945 dikenal dengan executive heavy, ${ }^{1}$ seperti pengalaman dua masa pemerintahan Presiden Soekarno (1959-1967) dan Presiden Soeharto

\footnotetext{
${ }^{1}$ Sri Soemantri M., UUD 1945 Kedudukan dan Aspek-Aspek Perubahannya, Unpad Press, Bandung 2001, hlm. 22; Bagir Manan, "Reformasi Konstitusi Menuju Keseimbangan Kewenangan Eksekutif dan Legislatif", Jurnal Forum Indonesia Satu, Civility, Vol. 1 No. 1 Juli-September 2001, hlm. 65. Jimly Asshiddiqie, “Telaah Kritis Mengenai Perubahan Undang-Undang Dasar 1945", Jurnal Indonesia Satu, Civility, Vol. 1 No. 2 November 2001 - Januari 2002, hlm. 41; Philipus M. Hadjon, Lembaga Tertinggi dan Lembaga-Lembaga Tinggi Negara Menurut UUD 1945, Suatu Analisa Hukum Kenegaraan, Bina Ilmu, Surabaya, 1087, hlm. 41; Muhammad Ridhwan Indra, Dalam UUD 1945 Kekuasaan Eksekutif Lebih Menonjol (Executive Heavy), Haji Masagung, Jakarta, 1988, hlm. 7-8.
} 
(19672-1998). Hal yang demikian akan selalu terulang kembali, jika tidak ada pengawasan yang seimbang antara lembaga negara, yaitu eksekutif, legislatif, dan yudisial. Untuk itu, kontrol harus dilakukan oleh kekuasaan yang sama secara terbatas antar lembaga. Kontrol itu perlu untuk menjaga keseimbangan, mencegah dominasi, dan penyalahgunaan wewenang. Apabila tidak, akan terjadi dominasi, menekan kekuasaan yang lain, dan cenderung disalahgunakan, seperti dikatakan Lord Acton di dalam suratnya yang ditujukan kepada Bishop Mandell Creighton pada tahun 1887, power tends to corrupt and absolute power corrupt absoluty (kekuasaan cenderung untuk disalahgunakan dan kekuasaan yang mutlak cenderung disalahgunakan secara mutlak). ${ }^{3}$

UUD 1945 yang executive heavy yang dipraktikkan pada masa pemerintahan Presiden Soekarno (1959-1967) dan Presiden Soeharto (19674-1998) mengakibatkan organ legislatif dan yudisial tidak dapat mengimbangi dominasi kekuasaan eksekutif. Hal tersebut dapat dilihat dari ketentuan Pasal 19 ayat (1) UUD 1945 yang menyatakan "Susunan Dewan Perwakilan Rakyat ditetapkan dengan undang-undang". Presiden memegang kekuasaan membentuk undang-undang dengan persetujuan Dewan Perwakilan Rakyat (Pasal 5 ayat (1) UUD 1945). Tiap-tiap undangundang menghendaki persetujuan Dewan Perwakilan Rakyat (Pasal 20 ayat (1)). Dengan UUD 1945 yang executive heavy pada masa pemerintahan Soekarno, Presiden mendominasi kekuasaan terbukti dengan bongkar pasang kabinet, para pemimpin lembaga tertinggi dan tinggi negara diberi status menteri sebagai pembantu Presiden yang berarti legislatif di bawah kekuasaan dan kontrol eksekutif. Begitupula pada masa pemerintahan Soeharto yang bertekad "melaksanakan UUD 1945 secara murni dan konsekuen", yang dalam kenyataannya tidak lebih baik dari masa pemerintahan Presiden Soekarno. Praktik pemerintahan dari dua

${ }^{2}$ Ketetapan MPRS Republik Indonesia No. XXXIII/MPRS/1967 Tentang Pencabutan Kekuasaan Pemerintahan Negara dari Presiden Soekarno. Pasal 4 menyatakan: “Menetapkan berlakunya Ketetapan MPRS No. XV/MPRS/1966 sebagai pejabat Presiden berdasarkan Pasal 8 UUD 1945 hingga dipilihnya Presiden oleh MPR hasil pemilihan umum".

${ }^{3}$ Wikipedia, the free encyclopedia.

${ }^{4}$ Ketetapan MPRS Republik Indonesia No. XXXIII/MPRS/1967 Tentang Pencabutan Kekuasaan Pemerintahan Negara dari Presiden Soekarno secara umum, orang mengenal mulainya Orde baru sejak 1966 (keluarnya Supersemar) namun secara formal konstitusional sebenarnya adalah tahun 1967. 
masa pemerintahan tersebut memperlihatkan dominasi kekuasaan Presiden yang sangat kuat sehingga praktik ketatanegaraan pada masa pemerintahan Orde Lama di bawah kepemimpinan Presiden Soekarno (1959-1967) dan Soeharto (1967-1988) tidak menciptakan atau membuat tradisi pengawasan dan keseimbangan antara lembaga negara, khususnya pengawasan antara legislatif dan eksekutif sebagaimana diamanatkan oleh konstitusi.

Perubahan UUD 1945 perlu dilakukan oleh karena adanya beberapa kelemahan UUD 1945 yang memungkinkan tampilnya pemerintahan yang tidak demokratis. Kelemahan-kelemahan tersebut adalah:

Pertama, UUD 1945 memberikan dasar kuat kepada kekuasaan eksekutif (populer disebut dengan executive heavy), tidak adanya checks and balances. Presiden menjadi penentu semua agenda politik nasional, karena selain Presiden sebagai kepala negara dan kepala pemerintahan, Golongan Karya sangat dominan di MPR dan DPR. Presiden juga pemegang kekuasaan di bidang legislatif. Pengawasan dari lembaga yudisial maupun DPR tidak dapat berjalan efektif; tidak efektifnya Kekuasaan MPR dan DPR lebih terletak pada aspek politik, yaitu karena kedua lembaga negara tersebut didominasi oleh kekuatan politik Presiden yaitu Golongan Karya.

Kedua, UUD 1945 memuat pasal-pasal yang multi-interpretable atau multitafsir sehingga bisa ditafsirkan dengan bermacam-macam arti. Akan tetapi yang harus diterima adalah tafsir yang dibuat oleh Presiden, seperti kekuatan Pasal 7 yang menyatakan "Presiden dan Wakil Presiden memegang jabatannya selama masa lima tahun dan sesudahnya dapat dipilih kembali". Ketentuan pasal ini dapat ditafsirkan minimal dua macam penafsiran, yaitu; dapat dipilih berkali-kali asalkan dilakukan setiap lima tahun atau ditafsirkan hanya dapat dipilih sekali lagi setelah masa jabatannya yang pertama.

Ketiga, UUD 1945 banyak memberi atribusi dan delegasi kepada Presiden untuk mengatur hal-hal penting dengan undang-undang maupun dengan Peraturan Pemerintah. Dalam mengatur beberapa hal penting. Presiden selalu berada pada posisi yang lebih menentukan daripada DPR sehingga banyak materi undang-undang yang bersumber pada kehendak Presiden saja.

Keempat, UUD 1945 terlalu percaya kepada semangat dan iktikad baik orang yang berkuasa, sehingga lebih menggantungkan pada semangat penyelenggaraan negara daripada mengatur pembatasan-pembatasan 
kekuasaan secara tegas. ${ }^{5}$

Rumusan UUD 1945 tentang semangat penyelenggaraan negara tidak dapat dijadikan sandaran untuk penyelenggaraan negara. UUD 1945 perlu mempertegas aturan dasar tentang kehidupan yang demokratis, supremasi hukum, pemberdayaan rakyat, penghormatan hak asasi manusia (HAM) dan otonomi daerah. Kelemahan UUD ini membuka peluang bagi berkembangnya praktek penyelenggaraan negara yang tidak sesuai dengan pembukaan UUD 1945. Antara lain tidak adanya checks and balances antara lembaga negara dan kekuasaan terpusat pada presiden. Infrastruktur politik yang dibentuk, antara lain partai politik dan organisasi masyarakat, kurang mempunyai kebebasan berekspresi sehingga tidak dapat berfungsi sebagaimana mestinya. ${ }^{6}$

Dengan kelemahan-kelemahan itu, maka selama menggunakan UUD 1945 (sebelum diubah), Negara Indonesia tidak pernah terselenggara secara demokratis. Untuk mencegah berulangnya kecenderungan otoritarian, UUD 1945 harus diperbaharui untuk lebih mengukuhkan dan menjamin pelaksanaan demokrasi, sehingga negara berdasarkan hukum, benar-benar sebagaimana sarana mewujudkan keadilan sosial bagi seluruh rakyat Indonesia. Perubahan Undang-Undang Dasar 1945 untuk menyeimbangkan kekuasaan antara legislatif, eksekutif, yudisial yang dianggap executive heavy, sehingga tercipta checks and balances sistem. ${ }^{7}$

Pada perubahan pertama substansi yang diubah menyangkut dua hal. Pertama, memberdayakan Dewan Perwakilan Rakyat, kedua, membatasi kekuasaan Presiden. Semula Presiden memegang kekuasaan membentuk undang-undang dengan persetujuan DPR, maka pada perubahan pertama ini terjadi kebalikannya. ${ }^{8}$ Artinya, Dewan Perwakilan Rakyat memegang kekuasaan membentuk undang-undang (ketentuan Pasal 20 ayat (1), sedangkan Presiden berhak mengajukan rancangan undang-undang kepada DPR (ketentuan Pasal 5 ayat (1)). Dengan dan melalui perubahan tersebut, kedudukan DPR menjadi kuat, tidak hanya terbatas pada penetapan undang-undang, akan tetapi juga berperan

${ }^{5}$ Moh. Mahfud MD, Hukum dan Pilar-pilarDemokrasi, Gama Media, Yogyakarta, 1999, hlm. 116-117.

${ }^{6}$ MPR RI, Panduan dalam Memasyarakatkan Undang-Undang Dasar Negara Republik Indonesia Tahun 1945, Sekjen MPR RI, 2003, hlm. 14

${ }^{7}$ Risalah Sementara Rapat Pleno Ke-25 Panitia Ad Hoc. 1 BP - MPR 6 September 2001, Sekretariat Jenderal MPR, Jakarta, 2001, hlm. 10-17

${ }^{8}$ Sri Soemantri M., UUD 1945..., op.cit., hlm. 21 
terhadap pengangkatan para pejabat negara serta pemberian amnesti dan abolisi. Dalam hal ini diperlukan adanya pertimbangan Dewan Perwakilan Rakyat. Bahkan dalam menerima penempatan duta negara lain, dengan adanya perubahan pertama itu, presiden "harus" memperhatikan pertimbangan Dewan Perwakilan Rakyat ${ }^{9}$ (ketentuan Pasal 13 ayat (2) dan ayat (3)). Dalam usaha memperkuat kedudukan Dewan Perwakilan Rakyat, pada perubahan kedua ditentukan, bahwa DPR memiliki fungsi pengawasan sebagaimana diatur dalam Pasal 20 A ayat (1) yang menyatakan "Dewan Perwakilan Rakyat memiliki fungsi legislasi, fungsi anggaran, dan fungsi pengawasan". Materi muatan tersebut merupakan ketentuan konstitusional, fungsi pengawasan yang semula diatur dalam penjelasan UUD 1945, bahkan ada yang diatur dalam peraturan tata tertib Dewan Perwakilan Rakyat. ${ }^{10}$

Dalam sistem checks and balances, Presiden sebagai kepala eksekutif mempunyai kedudukan yang sederajat, tetapi saling mengendalikan dengan lembaga Parlemen sebagai pemegang kekuasaan legislatif. Sesuai dengan prinsip presidensial, Presiden tidak dapat membubarkan Parlemen, begitu sebaliknya Parlemen juga tidak dapat menjatuhkan Presiden. Parlemen hanya dapat menuntut pemberhentian Presiden jika Presiden terbukti melakukan pelanggaran hukum; itupun biasanya dibatasi oleh konstitusi hanya untuk jenis-jenis tindak pidana tertentu saja, sedangkan dalam sistem pemerintahan parlementer, Parlemen secara mudah dapat menjatuhkan kabinet hanya karena alasan politik, yaitu melalui mekanisme yang bisa disebut dengan "mosi tidak percaya" (vote of cencure) terhadap kinerja kabinet dan terhadap kebijakan pemerintahan (beleid). Kebiasaan dalam sistem presidensial yang ingin dikembangkan di Indonesia. ${ }^{11}$

Dalam kaitannya dengan checks and balances itu pula diajukan gagasan perubahan terhadap sistem parlemen dari supremasi Majelis Permusyawaratan Rakyat yang terdiri dari tiga unsur, Dewan Perwakilan Rakyat, Utusan Daerah dan Utusan Golongan menjadi parlemen sistem bikameral (dua kamar) yang terajut dalam hubungan checks and balances dengan lembaga lainnya khususnya dengan lembaga eksekutif dan yudikatif. Gagasan ini menghendaki agar parlemen terdiri dari lembaga

${ }^{9} \mathrm{Ibid}, \mathrm{hlm} .23$

${ }^{10} \mathrm{Ibid}, \mathrm{hlm} .25$

${ }^{11}$ Jimly Asshiddiqie, Format Kelembagaan Negara dan Pergeseran Kekuasaan Dalam UUD 1945, FH UII Press, Yogyakarta, 2003, hlm. 80 
perwakilan politik yaitu Dewan Perwakilan Rakyat dan lembaga perwakilan teritorial yaitu Dewan Perwakilan Daerah, karena Dewan Perwakilan Daerah mempunyai fungsi legislasi sebagai layaknya wakil rakyat yang dipilih melalui pemilu. Kedua lembaga ini semula digagas dengan fungsi seperti parlemen yang mempunyai Dewan Perwakilan Rakyat dan Senat seperti parlemen bikameral di negara Amerika Serikat yang mempunyai fungsi legislasi dan fungsi-fungsi parlemen lainnya seperti fungsi pengawasan dan fungsi anggaran. ${ }^{12}$ Tetapi gagasan parlemen bikameral di Indonesia tidak persis seperti parlemen bikameral di negara Amerika Serikat karena di dalam parlemen bikameral Indonesia, Presiden ikut memegang kekuasaan legislatif sehingga tidak dapat memveto Rancangan Undang-Undang yang telah lolos di parlemen.

Bertitik tolak dari uraian di atas, permasalahan yang dirumuskan adalah: Pertama, apakah terdapat sistem pengawasan dan keseimbangan antara DPR dan Presiden sebelum dan sesudah perubahan UUD 1945? Kedua, faktor-faktor apa sajakah yang menjadi kendala dalam sistem pengawasan dan keseimbangan antara DPR dan Presiden? Ketiga, sistem dan mekanisme check and balances seperti apa yang dikandung di dalam UUD 1945 hasil perubahan dan bagaimanakah seharusnya hal tersebut dikonsepkan atau diatur.

\section{Checks and Balances antara DPR dan Presiden}

Perubahan Undang-Undang Dasar 1945 menurut Sri Soemantri Martosoewignjo dimaksudkan sebagai upaya untuk menghindari manipulasi kekuasaan seperti yang pernah terjadi pada masa pemerintahan Soekarno dan Pemerintahan Soeharto. ${ }^{13}$ Di samping itu, perubahan itu untuk menyeimbangkan kekuasaan antara legislatif, eksekutif, dan yudikatif yang dianggap executive heavy, sehingga tercipta checks and balances system. ${ }^{14}$

Pada perubahan pertama, substansi yang diubah menyangkut dua hal. Pertama, memberdayakan Dewan Perwakilan Rakyat, kedua,

\footnotetext{
${ }^{12}$ Moh. Mahfud MD., Perdebatan Hukum Tata Negara, LP3ES, Jakarta, 2007, hlm. 66

${ }^{13}$ Ibrahim R., Sistem Pengawasan Konstitusional AntaraKekuasaan Legislatif dan Eksekutif Dalam Pembaharuan UUD 1945, Disertasi Pascasarjana UNPAD, Bandung, 2003, hlm. 2

${ }^{14}$ Risalah Sementara Rapat Pleno ke-25 Panitia Ad Hoc 1 BP MPR, loc. Cit, hlm. 10-17, yang dikutip kembali oleh Ibrahim R, Ibid.
} 
membatasi kekuasaan Presiden. Semula Presiden memegang kekuasaan membentuk undang-undang dengan persetujuan DPR, maka pada perubahan pertama ini terjadi kebalikannya. ${ }^{15}$ Artinya, Dewan Perwakilan Rakyat memegang kekuasaan membentuk undang-undang (ketentuan Pasal 20 ayat (1)), sedangkan Presiden berhak mengajukan rancangan undang-undang kepada DPR (ketentuan Pasal 5 ayat (1)). Dengan dan melalui perubahan tersebut, kedudukan DPR menjadi kuat, tidak hanya terbatas pada penetapan undang-undang, akan tetapi juga berperan terhadap pengangkatan para pejabat negara serta pemberian amnesti dan abolisi. Dalam hal ini diperlukan adanya pertimbangan Dewan Perwakilan Rakyat, bahkan dalam menerima penempatan duta negara lain. Dengan adanya perubahan pertama itu, Presiden "harus" memperhatikan pertimbangan Dewan Perwakilan Rakyat (ketentuan Pasal 13 ayat (2) dan ayat (3)). ${ }^{16}$ Dalam usaha memperkuat kedudukan Dewan Perwakilan Rakyat, pada perubahan kedua ditentukan, bahwa DPR memiliki fungsi pengawasan sebagaimana diatur dalam Pasal 20 A ayat (1) yang menyatakan "Dewan Perwakilan Rakyat memiliki fungsi legislasi, fungsi anggaran, dan fungsi pengawasan". Materi muatan tersebut merupakan ketentuan konstitusional, fungsi pengawasan yang semula diatur dalam penjelasan UUD 1945, bahkan ada yang diatur dalam peraturan tata tertib Dewan Perwakilan Rakyat. ${ }^{17}$

Pengawasan Dewan Perwakilan Rakyat yang diatur dalam Pasal 20 ayat (1) UUD 1945 mempunyai arti sangat penting karena akhirnya Dewan Perwakilan Rakyat dapat mengusulkan kepada MPR dengan terlebih dahulu mengajukan permintaan kepada Mahkamah Konstitusi untuk memeriksa, mengadili, dan memutuskan pendapat DPR bahwa Presiden dan atau Wakil Presiden telah melakukan pelanggaran hukum sebagaimana ketentuan Pasal 7 A UUD 1945 yang dapat berakibat Presiden dan atau Wakil Presiden diberhentikan.

Pelaksanaan pengawasan jalannya pemerintahan sehari-hari oleh Dewan Perwakilan Rakyat merupakan hubungan kemitraan antara Presiden dengan Dewan Perwakilan Rakyat. Ada hubungan keseimbangan atau equilibrium yang disebut oleh Sri Soemantri, sebagaimana dikutip oleh Albert Hasibuan dengan istilah hubungan

\footnotetext{
${ }^{15}$ Sri Somantri, UUD 1945..., loc. cit., hlm. 21

${ }^{16} \mathrm{Ibid}$, hlm. 23

${ }^{17} \mathrm{Ibid}$, hlm. 25
} 
seimbang, selaras, dan serasi sehingga tidak terjadi saling dominasi yang sering terjadi dalam sistem presidensial ataupun sistem parlementer. ${ }^{18}$

Dalam sistem ketatanegaraan Indonesia berkedaulatan rakyat, berdasarkan hukum, dan penyelenggaraan pemerintahan negara berdasarkan konstitusi, sistem pengawasannya harus sesuai dengan yang ditetapkan di dalam undang-undang dasar. Dengan adanya pembagian kekuasaan dan pengawasan dalam praktik penyelenggaraan negara, maka kekuasaan negara dapat diatur, dibatasi, serta dikendalikan sehingga penyalahgunaan kekuasaan oleh penyelenggara negara yang sedang menduduki jabatan dalam lembaga-lembaga negara dapat dicegah dan ditanggulangi dengan sebaik-baiknya. Adanya perubahan UUD 1945 menjanjikan akan lebih ditingkatkannya mekanisme checks and balances antar lembaga negara.

Dalam sistem ketatanegaraan Indonesia, pengawasan terhadap eksekutif atau pemerintah yang dilakukan oleh DPR merupakan salah satu cara membatasi dan mengendalikan penguasa. Pada masa lalu, dalam praktik ketatanegaraan Indoesia, penyalahgunaan kekuasaan sebagai akibat lemahnya fungsi pengawasan oleh DPR telah mengakibatkan pertanggungjawaban pemerintah dalam penyelenggaraan pemerintahan yang bersih dan bertanggung jawab tidak terlaksana.

Sebagaimana dikemukakan di atas, pasca perubahan UUD 1945 menjanjikan lebih ditingkatkannya mekanisme checks and balances antar lembaga negara dalam sistem ketatanegaraan Indonesia. Di masa lalu, sebelum UUD 1945 diadakan perubahan, penerapan sistem pembagian kekuasaan (distribution of power) oleh MPR dan mekanisme checks and balances yang tidak jelas telah menimbulkan kecenderungan kepada arah sentralisasi kekuasaan oleh pihak eksekutif. Akibatnya, peran DPR sebagai alat kontrol atau pengawas terhadap eksekutif menjadi sangat lemah. Perubahan UUD 1945 telah memberikan posisi yang kuat terhadap lembaga pengawas. Hal ini sesuai dengan ketentuan Pasal 20 A ayat (1) yang menyatakan: “Dewan Perwakilan Rakyat memiliki fungsi legislasi, fungsi anggaran, dan fungsi pengawasan". Materi muatan tersebut merupakan ketentuan konstitusional, dimana semula hal ini diatur dalam peraturan yang lebih rendah dari Undang-Undang Dasar 1945, bahkan

${ }^{18}$ Albert Hasibuan dalam Bagir Manan, Kedaulatan Rakyat Hak Asasi Manusia dan Negara Hukum, Gama Media Pratama, Jakarta, 1996, hlm. 106. 
ada yang diatur dalam Peraturan Tata Tertib Dewan Perwakilan Rakyat. ${ }^{19}$

Miriam Budiardjo menyatakan sistem checks and balances (pengawasan dan keseimbangan) adalah sistem dimana setiap cabang kekuasaan dapat mengawasi dan mengimbangi cabang kekuasaan lainnya. ${ }^{20}$ Menurut Albert Hasibuan, ${ }^{21}$ sistem konstitusi yang merancang demokrasi adalah sistem checks and balances yang memberikan garansi serta memastikan adanya deliberation atau sistem konstitusi yang berisikan reasoning spirit of the constitution. Oleh karena itu, Undang-Undang Dasar 1945 yang demokratis itu bersifat pragmatis karena mempunyai sistem checks and balances diantara lembaga-lembaga negara. ${ }^{22}$

Dalam sistem checks and balances, Presiden sebagai kepala eksekutif mempunyai kedudukan yang sederajat, tetapi saling mengendalikan dengan lembaga parlemen sebagai pemegang kekuasaan legislatif. Sesuai prinsip presidensial, presiden tidak dapat membubarkan parlemen, begitu sebaliknya Parlemen juga tidak dapat menjatuhkan Presiden. Parlemen hanya dapat menuntut penghentian Presiden jika Presiden terbukti melakukan pelanggaran hukum, itupun biasa dibatasi oleh konstitusi hanya untuk jenis-jenis tindak pidana tertentu saja. Misalnya dalam konstitusi Amerika Serikat mengaitkannya dengan pernghianatan terhadap negara (treason), penyuapan dan korupsi (bribery and high crimes), serta pelanggaran-pelanggaran ringan tetapi dapat dikategorikan sebagai perbuatan tercela, (misdemeanours). Dalam sistem pemerintahan parlementer, Parlemen secara mudah dapat menjatuhkan kabinet hanya dengan alasan politik, yaitu melalui mekanisme yang biasa disebut dengan "mosi tidak percaya" (vate of cencure) terhadap kinerja kabinet dan terhadap kebijakan pemerintahan (beleids). Kebiasaan dalam sistem pemerintahan parlementer ini tidak dapat dijadikan acuan dalam sistem presidensial yang ingin dikembangkan di Indonesia. ${ }^{23}$

Undang-Undang Dasar Negara Republik Indonesia Tahun 1945 (disingkat UUD 1945) ${ }^{24}$ sebelum diadakan perubahan tidak memberikan

${ }^{19}$ Sri Soemantri, UUD 1945 Kedudukan..., loc.Cit., hlm. 25

${ }^{20}$ Miriam Budihardjo, Dasar-Dasar..., loc. Cit., hlm. 47

${ }^{21}$ Ibrahim R, Sistem Pengawasan..., loc. Cit, hlm. 47

${ }^{22}$ Ibid.

${ }^{23}$ Jimly Asshiddiqie, Format Kelembagaan ..., loc. Cit., hlm. 80-81

${ }^{24}$ Penulis menggunakan istilah Konstitusi sama artinya dengan Undang-Undang Dasar, mengikuti pendapat Sri Soemantri Martosoewignjo, Prosedur dan Sistem perubahan Konstitusi, Alumni Bandung, 1986, hlm. 1. Dalam literatur dikenal beberpa istilah 
ketentuan secara tegas, bahwa kekuasaan legislatif harus berada di tangan Dewan Perwakilan Rakyat. Hal ini diatur dalam Pasal 5 ayat (1) yang menyatakan "Presiden memegang kekuasaan membentuk undangundang dengan persetujuan Dewan Perwakilan Rakyat". Ketentuan Pasal 20 ayat (1) menyatakan "Anggota Dewan Perwakilan Rakyat berhak mengajukan rancangan undang-undang". Akan tetapi hak inisiatif mengajukan rancangan undang-undang itu, sifatnya hanya tambahan terhadap kewenangan utama yang dimiliki oleh Dewan Perwakilan Rakyat, akan tetapi dibandingkan dengan kewenangan utama membentuk undang-undang yang dimiliki oleh Presiden. Ketentuan ini memperlihatkan kedudukan yang tidak seimbang natara Presiden dan Dewan Perwakilan Rakyat di bidang Legislatif.

Ketidakseimbangan itu makin jelas terlihat dalam hal pembentukan Peraturan Pemerintah sebagai pengganti undang-undang (Perpu), sebagaimana diatur dalam Pasal 22 ayat (1) UUD 1945, yang menyatakan "Dalam hal ikhwal kegiatan yang memaksa, Presiden berhak menetapkan peraturan pemerintah sebagai pengganti undang-undang". Begitu pula dalam hal rancangan undang-undang yang diprakarsai oleh Dewan Perwakilan Rakyat, meskipun disetujui oleh Dewan Perwakilan Rakyat, apabila tidak disahkan oleh Presiden, maka rancangan tadi tidak boleh dimajukan lagi dalam persidangan Dewan Perwakilan Rakyat masa itu. Hal ini sesuai dengan ketentuan Pasal 21 ayat (2) UUD 1945. Bahkan lebih jauh lagi, dalam pembentukan peraturan perundang-undangan, yang disebut sebagai policy rules ${ }^{25}$ dianggap dengan sendirinya berada di tangan Presiden. Yang di dalam praktik tercerminkan kewenangannya ketika mengeluarkan Keputusan Presiden ${ }^{26}$ yang bersifat mandiri, dalam arti tidak dalam rangka melaksanakan undang-undang. Bahkan dalam praktik cenderung hanya sekali jenis surat Keputusan Presiden bersifat mandiri, yang mengatur hal-hal yang kadang-kadang seharusnya diatur dalam undang-undang. ${ }^{27}$ Dari kasus sebagaimana tersebut di atas, maka tampak jelas, bahwa kedudukan Presiden dalam bidang legislatif jauh

untuk konstitusi dari berbagai bahasa, yaitu grondwet (Belanda), Die Grundsatzung (Jerman), Dastur (Arab), Constitutio (Latin) Constitution (Inggris) Samwidhana (Sansekerta).

${ }^{25}$ Jimly Asshiddiqie, Format..., hlm. 182

${ }^{26}$ Berdasarkan Undang-undang No. 10 tahun 2004, Keputusan Presiden yang mengatur diberi nama Peraturan Presiden.

${ }^{27}$ Jimly Asshiddiqie, Format ..., op cit., hlm. 182 
lebih besar daripada kedudukan Dewan Perwakilan Rakyat.

Perubahan UUD 1945 yang dilakukan oleh MPR selain merupakan perwujudan tuntutan reformasi, juga sejalan dengan pidato Ir. Soekarno yang menyatakan antara lain: "Bahwa ini adalah sekedar UUD Sementara, UUD kilat, bahwa barangkali boleh dikatakan pula istilah revolutie ground wet. Nanti kita membuat UUD yang lebih sempurna dan lengkap" ${ }^{28}$

Selanjutnya tuntutan itu diwujudkan secara komprehensip, bertahap, sistematis dalam empat kali perubahan UUD 1945 pada empat sidang MPR sejak tahun 1999 sampai dengan tahun 2002.

Perubahan UUD 1945 menurut Sri Soemantri Martosoewigjo, dimaksudkan sebagai upaya untuk menghindari manipulasi kekuasaan seperti yang pernah terjadi pada masa pemerintahan Soekarno dan pada masa pemerintahan Soeharto, di samping itu, perubahan itu untuk menyeimbangkan kekuasaan antara legislatif, eksekutif, dan yudikatif yang dianggap executive heavy, sehingga tercipta checks and balances. ${ }^{29}$

Sebelum perubahan UUD 1945, ketentuan yang mengatur DPR terdiri dari empat pasal yaitu: Pasal 19, Pasal 20, Pasal 21 dan pasal 22. setelah diamandemen ketentuan yang mengatur DPR bertambah menjadi 7 pasal yaitu: Pasal 19, Pasal 20A, Pasal 21, Pasal 22, Pasal 22A, dan Pasal 22B.

Sedangkan mengenai kekuasaan pemerintahan, ketentuan yang mengaturnya terdiri dari 12 pasal, yaitu: Pasal 4, Pasal 5, Pasal 6, Pasal 7, Pasal 8, Pasal 9, Pasal 10, Pasal 11, Pasal 12, Pasal 13, Pasal 14, dan Pasal 15. Setelah perubahan UUD 1945, kekuasaan pemerintahan negara diatur dalam 17 pasal, yaitu: Pasal 4, Pasal 5, Pasal 6, Pasal 6A, Pasal 7, Pasal 7A, Pasal 7B, Pasal 7C, Pasal 8, Pasal 9, Pasal10, Pasal 11, Pasal 12, Pasal 13, Pasal 14, Pasal 15, dan Pasal 16.

Perubahan pertama UUD 1945 substansi yang dirubah menyangkut dua hal: (1) Memberdayakan MPR; (2) Membatasi kekuasaan eksekutif (Presiden). ${ }^{30}$ Semula Presiden memegang kekuasaan membentuk undangundang dengan persetujuan DPR, maka pada perubahan pertama ini terjadi kebalikannya yaitu DPR memegang kekuasaan membentuk UU sesuai dengan Pasal 20 ayat (1), sedangkan Presiden berhak mengajukan

${ }^{28}$ Moh. Mahfud MD., Demokrasi dan KonstitusiDi Indonesia, Rineka Cipta, Jakarta, 2001, hlm. 139

${ }^{29}$ Risalah Sementara Rapat Pleno ke-25 Panitia Ad Hoc 1 BP MPR, loc cit., hlm. 10-17

${ }^{30}$ Sri Soemantri, UUD 1945, Kedudukan..., loc. Cit., hlm. 21 
RUU pada DPR sesuai dengan Pasal 5 ayat (1). ${ }^{31}$ Perubahan kedua lebih memberdayakan DPR dalam menjalankan fungsinya sebagai lembaga perwakilan yang dipilih oleh rakyat untuk memperjuangkan aspirasi dan kepentingannya. Demikian juga diharapkan DPR dapat lebih kuat dalam rangka menjalankan prinsip checks and balances terhadap Presiden dan lembaga-lembaga negara lainnya. Perubahan ketiga, mengatur pemilihan Presiden dan Wakil Presiden secara langsung, yaitu impeachment terhadap Presiden dan/atau Wakil Presiden, membentuk Dewan Perwakilan Daerah dan menegakkan kekuasaan kehakiman dengan membentuk lembaga baru yaitu Mahkamah Konstitusi dan Komisi Yudisial. Perubahan keempat menyempurnakan ketentuan dalam melakukan perubahan UUD 1945 serta menyempurnakan Aturan Peralihan dan Aturan Tambahan. ${ }^{32}$

Latar belakang MPR hasil pemilu tahun 1999 mengadakan perubahan terhadap UUD 1945 karena terdapat lima alasan sebagai berikut:

1. Praktik ketatanegaraan selama ini penuh dengan rekayasa dan usahausaha lain serta belum mampu menciptakan pemerintahan yang stabil dan demokratis disebabkan banyaknya kelemahan pada UUD 1945;

2. Sesuai UUD 1945, MPR merupakan pelaksana sepenuhnya kedaulatan rakyat dengan kekuasaan tidak terbatas, sehingga rakyat sendiri kehilangan kedaulatannya;

3. Pancasila merupakan norma dasar yang tidak langsung bersifat operasional. Karena itu harus dijabarkan dalam pasal-pasal sesuai dengan perkembangan jaman;

4. UUD 1945 masih bersifat sementara. Hal ini berdasarkan pada pidato Presiden Soekarno pada rapat penutupan Panitia Persiapan Kemerdekaanm Indonesia (PPKI) pada tanggal 18 Agustus 1945;

5. UUD 1945 dipandang terlalu sumir, ringkas dan bersifat executive heavy. Selain itu masih belum lengkapnya peraturan tentang HAM, lemahnya pembatasan kekuasaan dan tidak memahaminya sistem checks and balances. $^{33}$

${ }^{31}$ Pengesahan kewenangan membentuk undang-undang dari sebelumnya ditangan Presiden dialihkan kepada DPR merupakan langkan konstitusional untuk meletakkan secara tepat fungsi-fungsi lembaga negara sesuai bidang tugasnya masing-masing, yaitu DPR sebagai lembaga pembentuk undang-undang dan Presiden sebagai lembaga pelaksana undang-undang.

${ }^{32}$ Sekjen MPR RI, Latar belakang..., loc cit., hlm. 203.

${ }^{33}$ Sumbang saran tentang perubahan UUD 1945 oleh the Habibi Center, hlm. 3 
Sejarah ketatanegaraana Republik Indonesia telah membuktikan bahwa setiap penyimpangan terhadap kemurnian Pancasila dan UUD 1945 senantiasa membuahkan kekacauan negara dan kesengsaraan rakyat. Dalam sejarah politik dan kenegaraan, kita belum pernah melaksanakan segala pesan yang terkandung di dalam UUD 1945 secara konsekuen. Penyimpangan dan penyelewengan terhadap kemurnian pelaksanaan pasal-pasal UUD 1945 disebabkan adanya penafsiran secara sepihak dan adanya rekayasa politik yang dalam pelaksanaanya oleh para penyelenggara negara dan para pemimpin pemerintahan yang semangatnya bukan untuk kepentingan bangsa dan negara melainkan demi kepentingan kekuasaan pribadi maupun kelompok.

Apabila kita melihat Penjelasan UUD 1945 butir IV sebagaimana telah diingatkan oleh para founding fathers bahwa UUD 1945 bersifat singkat, supel dan elastis. Namun yang sangat penting adalah semangat, semangat para penyelenggara negara dan semangat para pemimpin pemerintahan. Harus diakui bahwa banyak ketentuan-ketentuan pada pasal-pasal UUD 1945 yang sejak lima puluh tahun yang lalu hingga saat ini belum pernah dijabarkan ke dalam undang-undang untuk dapat dioperasionalkan, antara lain sistem politik demokrasi Pancasila, sistem demokrasi ekonomi Pancasila dan lainlain pasal yang secara langsung dapat menjamin terwujudnya suatu pemerintahan yang stabil dan demokrasi agar mampu mensejahterakan, mencerdaskan dan melindungi segenap rakyat Indonesia. ${ }^{34}$

Apabila kita cermati Penjelasan UUD 1945 mengenai sistim pemerintahan negara dan penjelasan tentang kekuasaan kehakiman yang telah dielaborasi melalui Tap MPRS No. XX/MPRS/1966, nampak telah ada checks and balances antara lembaga eksekutif, legislatif dan lembaga yudikatif. Dari pengalaman membuktikan bahwa sistim checks and balances tidak berjalan dengan baik dikarenakan hal-hal sebagai berikut.

1. Adanya rekayasa politik yang menyebabkan kekuasaan tersentralisasi pada lembaga eksekutif;

2. Masih melekatnya sifat primordialisme, feodalisme dan prinsip yang masih mengedepankan hubungan kekeluargaan dan bukan berdasarkan ketentuan hukum;

3. Belum adanya undang-undang tentang kepresidenan sehingga mengaburkan ketajaman kontrol sosial lembaga-lembaga lainnya atau checks and balances. ${ }^{35}$

\footnotetext{
${ }^{34}$ Ibid., hlm. 4

${ }^{35}$ Ibid., hlm. 5
} 
Dengan memperhatikan uraian sebagaimana tersebut di atas, meyakinkan kita bahwa UUD 1945 sebagai sebagian hukum dasar memang harus diadakan perubahan agar mampu mewujudkan suatu kehidupan bangsa dan negara sesuai dengan amanah Pembukaan UUD 1945 yang merupakan jiwa dan cita-cita proklamasi UUD 1945.

Adanya perubahan UUD 1945 menjanjikan lebih ditingkatkannya mekanisme checks and balances antar lembaga legislatif dan eksekutif. Di masa lalu, penerapan sistem pembagian kekuasaan (distribution of powers) oleh MPR, serta mekanisme checks and balances tidak pernah dirumuskan secara eksplisit dalam perundang-undangan, sehingga sistem pemisahan kekuasaan (separation of power) menjadi tidak jelas, yang pada akhirnya memunculkan kecenderungan ke arah sentralisasi kekuasaan oleh pihak eksekutif. Akibatnya, DPR perannya sebagai alat kontrol menjadi sangat lemah. Setelah UUD 1945 mengalami perubahan, persetujuan DPR tidak hanya diberikan dalam kaitannya dengan pernyataan perang dan membuat perdamaian, melainkan juga dalam membuat perjanjian internasional sebagaimana diatur dalam Pasal 11. Perubahan UUD 1945 pun mengharuskan Presiden untuk meminta persetujuan DPR manakala mengangkat duta dan bahkan menerima duta negara lain. Hal ini sesuai dengan ketentuan Pasal 13 ayat (2) dan ayat (3). Demikian pula halnya dengan memberi grasi, amnesti, tanda jasa serta abolisi dan berbagai gelar serta tanda jasa lainnya, Presiden tidak mungkin lagi bertindak tanpa pengawasan DPR, hal ini sesuai dengan ketentuan Pasal 14 dan Pasal 15 UUD 1945.

Dengan adanya sistem checks and balances, maka kekuasaan negara dapat diatur, dibatasi dan bahkan dikontrol dengan sebaik-baiknya sehingga penyalahgunaan kekuasaan oleh aparat penyelenggara negara ataupun pribadi-pribadi yang kebetulan sedang menduduki jabatan dalam lembaga-lembaga negara yang bersangkutan dapat dicegah dan ditanggulangi dengan sebaik-baiknya. Meskipun demikian, sistem pengawasan dalam praktek penyelenggaraan negara pasca perubahan UUD 1945 masih menyisakan beberapa permasalahan yang perlu dikritisi bersama. Walaupun MPR telah berusaha mengadakan perubahan UUD 1945 secara tuntas, tetapi terkesan menciptakan sistem pemerintahan yang tidak jelas dan menghasilkan rumusan pasal-pasal yang tidak tuntas.

Dalam beberapa waktu terakhir, gagasan mengenai perlunya dilakukan revisi atau penyempurnaan terhadap UUD 1945 kembali mencuat. Dalam perkembangannya, gagasan tersebut terus bergulir dan 
banyak menuai respon positif sejumlah kalangan. Berbagai persoalan tentang ketatanegaraan yang muncul akhir-akhir ini, seperti persoalan mengenai belum efektifnya peran Dewan Perwakilan Daerah (DPD) dan ketidakharmonisan hubungan-hubungan antara lembaga negara, turut menjadi pemicu mencuatnya gagasan mengenai perlunya dilakukan amandemen kelima UUD 1945. ${ }^{36}$

Hasil amandemen UUD 1945 (1999-2002) telah membawa berbagai perubahan sangat signifikan bagi sistem ketatanegaraan yang secara langsung mempengaruhi struktur dan mekanisme struktural organ-organ negara Republik Indonesia. Berbagai perubahan tersebut diantaranya, penegasan prinsip kedaulatan rakyat (demokrasi) dan negara hukum, perubahan sistem hubungan pusat-daerah dan muncul lembaga-lembaga negara baru seperti, Dewan Perwakilan Daerah (DPD), Dewan Penasehat Presiden (DPP), Mahkamah Konstitusi (MK), dan Komisi Yudisial (KY). Namun di sisi lain hasil amandemen UUD 1945 masih memiliki sejumlah kelemahan yang bisa memunculkan masalah-masalah baru dalam ketatanegaraan di Indonesia. Sistem perwakilan bikameral yang digariskan dalam amandemen ketiga UUD 1945 bukan sistem bikameralisme murrni yang menjamin adanya keseimbangan atau checks and balances antara kedua kamar di parlemen. Ketiga, konsep pendistribusian kekuasaan (distribution of power) lembaga negara yang dianut oleh UUD 1945 hasil amandemen tidak proporsional dan tidak sesuai dengan prinsip checks and balances. ${ }^{37}$

Bila dikaji secara mendalam, ada tiga faktor utama yang menyebkan hasil amandemen UUD 1945 masih memiliki sejumlah kelemahan. Ketiga faktor tersebut, yaitu Pertama, MPR sebagai satu-satunya institusi negara yang mendapat mandat dari rakyat dan memiliki kewenangan untuk melakukan amandemen UUD 1945 sesuai dengan Pasal 37 UUD 1945, pada waktu melakukan amandemen UUD 1945 tidak memiliki kejelasan paradigma perubahan dan kerangka kerja (framework), sehingga menyebabkan hasil amandemen UUD 1945 menjadi bersifat parsial, sepotong-potong dan tambal sulam; Kedua, kuatnya tarik menarik kepentingan politik (political interest) dan tawar menawar politik (bergaining politic) para elit politik dan perumusan kaidah-kaidah yang akan dituangkan ke dalam pasal-pasal perubahan UUD 1945; Ketiga,

${ }^{36}$ Firdaus Arifin, Menuju Amandemen Kelima UUD 1945, 30 April 2007, www.MPR.go.id

${ }^{37}$ Ibid. 
minimnya keikutsertaan rakyat (public participation) dalam proses amandemen UUD 1945. Hal ini tampak dari kinerja MPR yang tidak maksimal dan sungguh-sungguh dalam memberikan kesempatan kepada rakyat untuk berpartisipasi dalam proses amandemen UUD 1945. ${ }^{38}$

Kalaupun ada, proses sosialisasi dan penjaringan/penyerapan aspirasi rakyat, semuanya hanya sekedar formalitas guna memenuhi mekanisme dan prosedur yang ada. Hal ini padahal menjadi bagian paling penting dalam suatu proses amandemen UUD 1945 terutama dalam membangun sense of belonging dan keyakinan rakyat kepada hukum dasarnya. ${ }^{39}$

Secara prinsip, keberadaan UUD 1945 tidak lagi cukup mampu menjadi satu perangkat konstitusi yang dapat menjembatani dan memayungi semua proses politik kenegaraan. Upaya tambal sulam, sebagaimana yang telah dilakukan empat kali amandemen terhadap UUD 1945. Bandingkan dengan Thailan misalnya yang telah 14 kali melakukan amandemen konstitusinya. Sebaliknya, apabila pergantian konstitusi, dari UUD 1945 ke konstitusi baru telah terjadi dua kali, yakni, UUD RIS dan UUDS 1950, yang mana keduanya terintegrasikan dengan adanya Dekrit Presiden 5 Juli 1959, yang memutuskan kembali dengan menggunakan UUD 1945 sebagai konstitusi negara. Dalam upaya mengganti konstitusi, jika bisa berkaca pada proses perubahan konstitusi yang terjadi di Perancis. Kedua-duanya; amandemen atau konstitusi baru adalah upaya membangun penguatan sistem ketatanegaraan yang efektif, efisien, adil, dan adanya mekanisme checks and balances. ${ }^{40}$

Dalam mengajukan rekomendasi mekanisme pelaksanaan kekuasaan Presiden di masa mendatang, kajian ini menggunakan beberapa mekanisme yang efektif yang ditujukan untuk kebutuhan check and balances, yaitu: ${ }^{41}$

\section{Konsultasi:}

Presiden wajib meminta saran dan nasehat dari lembaga-lembaga terkait termasuk diantaranya DPR untuk mendapat usulan. Hasil konsultasi ini dijadikan pertimbangan utama untuk memutuskan hasil kebijakan akhir,

\footnotetext{
${ }^{38}$ Ibid.

${ }^{39} \mathrm{Ibid}$.

${ }^{40}$ Muradi, Menunggu Taring Politik DPD, Pikiran Rakyat Cyber Media, Selasa 27

${ }^{41}$ Tim Bidang Hukum Masyarakat Transparansi Indonesia, Pembatasan Kekuasaan Presiden RI: Kajian terhadap mekanisme pelaksanaan kekuasaan presiden ri dalam hukum positif indonesia, www.transparansi.or.id, majalah, edisi 11.
} September 2005. 


\section{Hearing;}

Presiden wajib mengadakan dengar pendapat secara terbuka di DPR untuk mendapatkan pertimbangan dan penilaian atas suatu kebijakan tertentu. Proses ini dapat dijadikan bahan untuk rumusan usulan dari DPR kepada Presiden yang disampaikan secara terbuka pula. Mekanisme ini dapat berjalan bersamaan dengan hak interpelasi DPR.

\section{Hak Veto}

Dimiliki oleh Presiden untuk menyatakan secara terbuka ketidaksetujuannya atas kebijakan yang diambil lembaga lain. Hak ini dapat menyebabkan kebijakan tersebut tidak berlaku.

\section{Penetapan seremonial}

Tindakan Presiden untuk mengesahkan dan/atau melantik suatu kebijakan final yang dihasilkan oleh lembaga lain.

Dalam sistem check and balances tidak hanya diperlukan dalam hubungan antara eksekutif dan legislatif, akan tetapi di dalam badan legislatif sendiri perlu adanya pertimbangan kekuasaan. Terbatasnya kewenangan yang dimiliki DPD memberikan gambaran bahwa sistem bikameral Indonesia tidak dibangun dalam kerangka check and balances. Keterbatasan itu memberi makna, gagasan menciptakan sistem dua kamar untuk mengakomodasi kepentingan daerah dalam menciptakan keadilan distribusi kekuasaan menjadi suatu yang utopis. Oleh karena itu dapat dimengerti jika DPD kehilangan kekuatan untuk mengklasifikasikan kepentingan politik daerah pada setiap proses perbuatan keputusan di tingkat nasional. Tidak hanya itu, kalau dilihat dari sudut pandang proses menjadi anggota parlemen, kewenangan terbatas yang dimiliki DPD menjadi tidak seimbang dengan tingkat kesulitan untuk menjadi anggota DPD. Setelah lolos menjadi calon, perjuangan untuk terpilih jauh lebih berat dan sulit dibandingkan menjadi anggota DPR. ${ }^{42}$

Sekurang-kurangnya ada tiga alasan mengapa DPD harus diperkuat: Pertama, sistem dua kamar lebih menjamin demokrasi dan kesejahteraan. Negara-negara besar dengan jumlah suku dan agama yang beragam umumnya mengadopsi sistem parlemen dua kamar. Negara-negara yang makmur secara ekonomi dan demokratis secara politik menerapkan parlemen

${ }^{42}$ Dadang Iskandar, Roh DPD Dimatisurikan, www.pikiran-rakyat/2007/032007 
dua kamar, seperti di negara Amerika Serikat, bikameralisme tidak lagi identik dengan negara federal, tetapi semakin lazim di negara kesatuan yang menerapkan desentralisasi seperti Indonesia. Sekarang ini, sekurangkurangnya terdapat 22 negara kesatuan yang mempraktikkan bikameralisme dengan berbagai variasinya. Bikameralisme juga tidak identik dengan sistem pemerintahan tertentu; Kedua, memperkuat sistem check and balances. Hadirnya kamar kedua (second chamber) mengandaikan terciptanya check and balances bukan hanya antar cabang kekuasaan negara (eksekutif, legislatif, yudikatif), tetapi juga di dalam cabang kekuasaan legislatif itu sendiri. Kamar kedua memungkinkan bekerjanya sistem double checks, yaitu terbukanya peluang pembahasan yang berlapis terhadap setiap produk legislatif yang berdampak bagi rakyat. Kamar kedua berfungsi, mengutip CF Strong (1973), untuk mencegah lahirnya undang-undang yang dibuat secara tergesa-gesa oleh satu majelis; Ketiga, memperjelas sistem parlemen Indonesia. Dengan memperkuat DPD, parlemen Indonesia semakin didorong ke arah bikameralisme murni, tidak pseudo-bicameralism seperti sekarang. Memperkuat DPD juga merupakan bentuk dari tindakan politik yang fair. Sebab, syarat untuk menjadi anggota DPD jauh lebih berat ketimbang menjadi anggota DPR. Untuk menjadi calon saja, anggota DPD harus memperoleh dukungan 1.000 sampai 5.000 tanda tangan pemilih. Mereka langsung berhadapan dengan rakyat, berbeda dengan DPR yang dipilih melalui partai politik. ${ }^{43}$

Namun, derajat legitimasi anggota DPD yang besar ini sama sekali tidak diimbangi secara sepadan dengan derajat kewenangannya sebagai wakil rakyat daerah. Oleh karena itu, ke depan, harus didorong terbentuknya sistem bikameral efektif, dengan cara; (1) DPD mempunyai wewenang legislasi, pengawasan dan anggaran; (2) DPD mempunyai wewenang untuk membahas dan ikut memutuskan seluruh RUU yang di bahas DPR; (3) DPD mempunyai hak inisiatif untuk mengajukan RUU, tetapi terbatas pada bidang-bidang tertentu yang terkait dengan urusan daerah; (4) susunan dan kedudukan MPR dirombak sehingga MPR hanya berfungsi sebagai rumah bersama bagi dua kamar DPR dan DPD. MPR tidak perlu memiliki sekretariat jenderal sendiri. MPR juga tidak memerlukan pimpinan parlemen, karena bisa dijabat secara bergantian oleh pimpinan DPR dan DPD; (5) DPD bisa dikonsentrasikan bukan hanya oleh kandidat independen, tetapi juga oleh anggota partai politik. ${ }^{44}$
${ }^{43}$ Ibid
${ }^{44}$ Ibid 


\section{Penutup}

Berdasarkan uraian di atas dapat disimpulkan bahwa, sebelum perubahan, Undang-Undang Dasar 1945 tidak mengatur pengawasan dan keseimbangan antara Dewan Perwakilan Rakyat dan Presiden, karena Undang-Undang Dasar 1945 menganut faham pembagian kekuasaan (distrution of powers) yang bersifat vertikal. Mekanisme pengawasan dan keseimbangan lebih bersifat formalitas karena dalam kenyataannya lebih executive heavy. Setelah terjadi perubahan UUD 1945, secara formal telah ada ketentuan yang mengatur tentang pengawasan dan keseimbangan antara DPR dan Presiden, namun masih menyisakan beberapa permasalahan yang perlu dikritisi.

Faktor-faktor yang menjadi kendala dalam sistem pengawasan dan Keseimbangan antara DPR dan Presiden adalah sebagai berikut:

1. Sebelum diubah, Undang-Undang Dasar 1945 membentuk struktur ketatanegaraan yang bertumpu pada kekuasaan tertinggi di tangan Majelis Permusyawaratan Rakyat yang sepenuhnya melaksanakan kedaulatan rakyat; 45

2. Undang-Undang Dasar 1945 menganut sistem pemerintahan presidensial dengan distribution of powers (pembagian kekuasaan), bukan pemisahan kekuasaan (separation of powers);

3. Sebelum perubahan, pemerintahan tidak dibagi dalam cabang-cabang pemerintahan yang sederajat;

a. Sistem dan mekanisme check and balances yang dikandung di dalam UUD 1945 hasil perubahan, secara prinsip, keberadaan UUD 1945 tidak lagi cukup mampu menjadi satu perangkat konstitusi yang dapat menjembatani dan memayungi semua proses politik kenegaraan.

Sistem check and balances tidak hanya diperlukan dalam hubungan antara eksekutif dan legislatif, akan tetapi di dalam badan legislatif sendiri perlu adanya perimbangan kekuasaan. Terbatasnya kewenangan yang dimiliki DPD memberikan gambaran bahwa sistem bikameral Indonesia tidak dibangun dalam kerangka check and balances. Hadirnya kamar kedua (scond chamber) mengandaikan terciptanya check and balances bukan hanya antar cabang kekuasaan negara (eksekutif, legislatif, yudikatif), tetapi juga di dalam cabang

\footnotetext{
${ }^{45}$ Pasal 1 ayat (2) UUD 1945 sebelum perubahan
} 
kekuasaan legislatif itu sendiri. Kamar kedua memungkinkan bekerjanya sistem double check, yaitu terbukanya peluang pembatasan yang berlapis terhadap setiap produk legislatif yang berdampak bagi rakyat, untuk itu perlu diakomodir kewenangan yang lebih kuat bagi DPD yang dituangkan dalam UUD 1945.

b. Bagaimana seharusnya hal tersebut dikonsepkan atau diatur.

Seharusnya check and balances diatur di dalam konstitusi yang memenuhi indikator-indikator check and balances yaitu:

1) DPR berhak membuat UU tapi dapat diveto oleh Presiden;

2) DPR dapat mementahkan veto Presiden apabila didukung oleh sekurang-kurangnya 2/3 dari kedua chamber;

3) Presiden dan DPR tidak dapat saling menjatuhkan karena kedudukannya sejajar dan terpisah;

4) Presiden dipilih oleh rakyat tetapi dapat dijatuhkan melalui imepachment oleh DPR jika ada alasan-alasan tertentu yang disebutkan di dalam konstitusi.

\section{Daftar Pustaka}

Sri Soemantri M., UUD 1945 Kedudukan dan Aspek-Aspek Perubahannya, Unpad Press, Bandung 2001.

Bagir Manan, "Reformasi Konstitusi Menuju Keseimbangan Kewenangan Eksekutif dan Legislatif", Jurnal Forum Indonesia Satu, Civility, Vol. 1 No. 1 Juli-September 2001.

Jimly Asshiddiqie, “Telaah Kritis Mengenai Perubahan Undang-Undang Dasar 1945", Jurnal Indonesia Satu, Civility, Vol. 1 No. 2 November 2001 - Januari 2002.

Jimly Asshiddiqie, Format Kelembagaan Negara dan Pergeseran Kekuasaan Dalam UUD 1945, FH UII Press, Yogyakarta, 2003, hlm. 80

Moh. Mahfud MD, Hukum dan Pilar-pilarDemokrasi, Gama Media, Yogyakarta, 1999.

, Perdebatan Hukum Tata Negara, LP3ES, Jakarta, 2007

MPR RI, Panduan dalam Memasyarakatkan Undang-Undang Dasar Negara Republik Indonesia Tahun 1945, Sekjen MPR RI, 2003

Philipus M. Hadjon, Lembaga Tertinggi dan Lembaga-Lembaga Tinggi Negara Menurut UUD 1945, Suatu Analisa Hukum Kenegaraan, Bina Ilmu, Surabaya, 1987. 
Muhammad Ridhwan Indra, Dalam UUD 1945 Kekuasaan Eksekutif Lebih Menonjol (Executive Heavy), Haji Masagung, Jakarta, 1988.

Ketetapan MPRS Republik Indonesia No. XXXIII/MPRS/1967 Tentang Pencabutan Kekuasaan Pemerintahan Negara dari Presiden Soekarno. 